\title{
Fluorescent Chemosensor for Detection of PPi Through the Inhibition of Excimer Emission in Water ${ }^{\dagger}$
}

\author{
Soon Young Kim and Jong-In Hong* \\ Department of Chemistry, College of Natural Sciences, Seoul National University, Seoul 151-742, Korea \\ *E-mail: jihong@snu.ac.kr \\ Received December 1, 2009, Accepted January 22, 2010
}

Key Words: Fluorescent chemosensor, Pyrophosphate, Pyrene, Excimer, Photoinduced Electron Transfer (PET)

Pyrophosphate $\left(\mathrm{P}_{2} \mathrm{O}_{7}{ }^{4-}, \mathrm{PPi}\right)$ is involved in energy transduction and metabolic processes within cells. For example, the concomitant release of PPi is indispensable to intracellular enzymatic reactions such as DNA polymerization catalyzed by DNA polymerase and the synthesis of cyclic adenosine monophosphate (cAMP), a second messenger used for signal transduction in many different organisms, catalyzed by adenylyl cyclase. ${ }^{1}$ Also, pyrosequencing, a method of DNA sequencing based on the "sequencing by synthesis" principle, is realized through the detection of PPi released during DNA polymerization. $^{2}$ In this regard, several research groups have focused on the development of selective PPi chemosensors.

Over the last 10 years, only a few chemosensors for PPi have been developed that have shown selectivity and sensitivity through fluorescence change in water. ${ }^{3}$ Due to the advantages of fluorescence detection methods, such as their high sensitivity, low cost, easy detection, versatility, and their possible applications in bioimaging, these techniques have gained a great deal of attention. Herein, we present a new fluorescent chemosensor based on a pyrenyl-Zn(II) DPA conjugate (DPA = dipicolylamine) which shows a selective quenching effect of excimer emission for PPi relative to other anions through a PET (Photoinduced Electron Transfer) process in water.

Sensor 1.2Zn was prepared as shown in Scheme $1 .^{3 \mathrm{c}}$ A pyrene group was attached to compound $\mathbf{2}$ by a Suzuki cross coupling reaction. Compound 1 was obtained in an overall $47 \%$ yield from compound 3 . Sensor $1 \cdot 2 \mathrm{Zn}$ was formed by the addition of an aqueous solution of 2 equiv $\mathrm{Zn}\left(\mathrm{NO}_{3}\right)_{2}$ to a DMSO solution of compound $\mathbf{1}$.

First, we examined the fluorescence emission change of $1 \cdot 2 \mathrm{Zn}$ $(5.56 \mu \mathrm{M})$ upon the addition of PPi (sodium salt) in $10 \mathrm{mM}$ HEPES buffer ( $\mathrm{pH} 7.4)$ at $25^{\circ} \mathrm{C}$ (Fig. 1). In the absence of PPi, the fluorescence emission of $1 \cdot 2 \mathrm{Zn}$ displayed a broad band (from $380 \mathrm{~nm}$ to $620 \mathrm{~nm}$ ) because of the pyrene excimer formation in water. ${ }^{4,6}$ Increasing the PPi (sodium salt) concentration up to 0.24 equiv resulted in a gradual decrease in the excimer emission $\left(\lambda_{\max }=473 \mathrm{~nm}\right)$ through the PET process. When 0.24 equiv PPi was added to a $1 \cdot 2 \mathrm{Zn}$ solution, the fluorescence intensity of $1 \cdot 2 \mathrm{Zn}$ showed a 12 -fold emission decrease at 473 $\mathrm{nm}$. However, further addition of PPi resulted in a slight enhancement of the fluorescence emission intensity at $509 \mathrm{~nm}$

${ }^{\dagger}$ This paper is dedicated to Professor Sunggak Kim on the occasion of his honorable retirement. and the excimer band of $\mathbf{1} \cdot 2 \mathrm{Zn}$ was bathochromic-shifted by $36 \mathrm{~nm}$.

Also, we investigated the fluorescence emission changes of $1.2 \mathrm{Zn}(5.56 \mu \mathrm{M})$ in the presence of various anions such as $\mathrm{F}^{-}$,
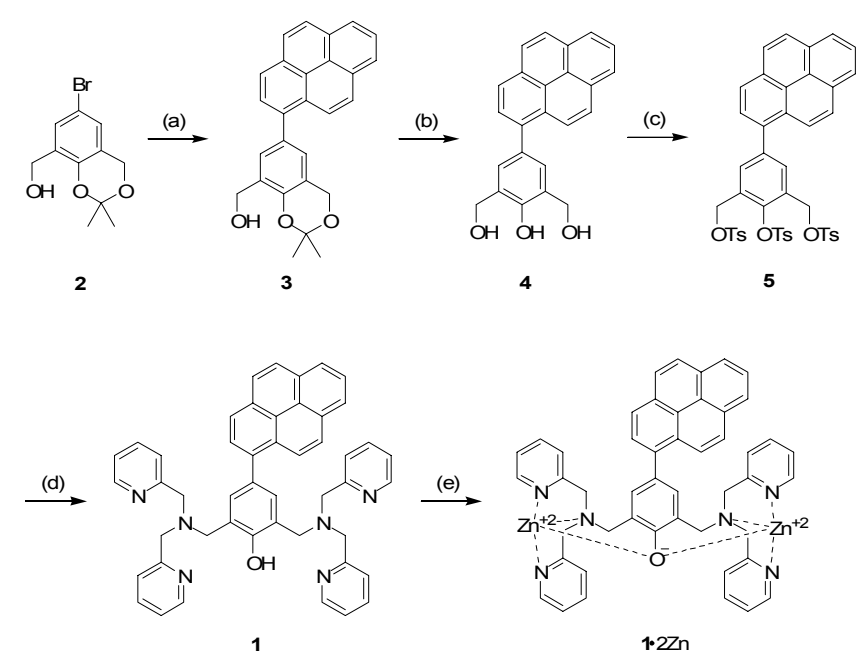

(a) Pyrene-1-boronic acid, $10 \mathrm{~mol} \% \mathrm{Pd}\left(\mathrm{PPh}_{3}\right)_{4}$, aq. $\mathrm{K}_{2} \mathrm{CO}_{3}$, THF (b) $1 \mathrm{~N} \mathrm{HCl}$, THF (c) aq. $\mathrm{NaOH}, \mathrm{TsCl}$, THF (d) i. $\mathrm{Cs}_{2} \mathrm{CO}_{3}, \mathrm{KI}$, dipicolylamine, $\mathrm{CH}_{3} \mathrm{CN}$ ii. aq. $\mathrm{KOH}, \mathrm{MeOH}(\mathrm{e}) \mathrm{Zn}\left(\mathrm{NO}_{3}\right)_{2} \cdot 6 \mathrm{H}_{2} \mathrm{O}, \mathrm{H}_{2} \mathrm{O}, \mathrm{MeOH}$

Scheme 1. Synthesis of Sensor $1 \cdot 2 \mathrm{Zn}$

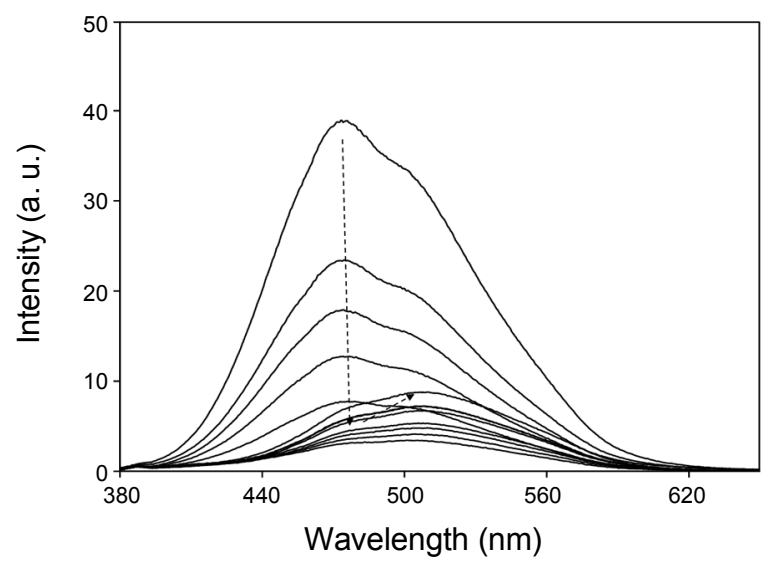

Figure 1. Fluorescence emission change $\left(\lambda_{\mathrm{ex}}=355 \mathrm{~nm}\right)$ of $\mathbf{1} \cdot 2 \mathrm{Zn}$ $(5.56 \mu \mathrm{M})$ upon the addition of PPi (sodium salt) in $10 \mathrm{mM}$ HEPES buffer (pH 7.4) at $25^{\circ} \mathrm{C}: \mathrm{PPi}$ (equiv) $=0,0.03,0.05,0.11,0.16,0.24$, $0.31,0.43,0.65,1.04,1.79,2.58,3.28$. 

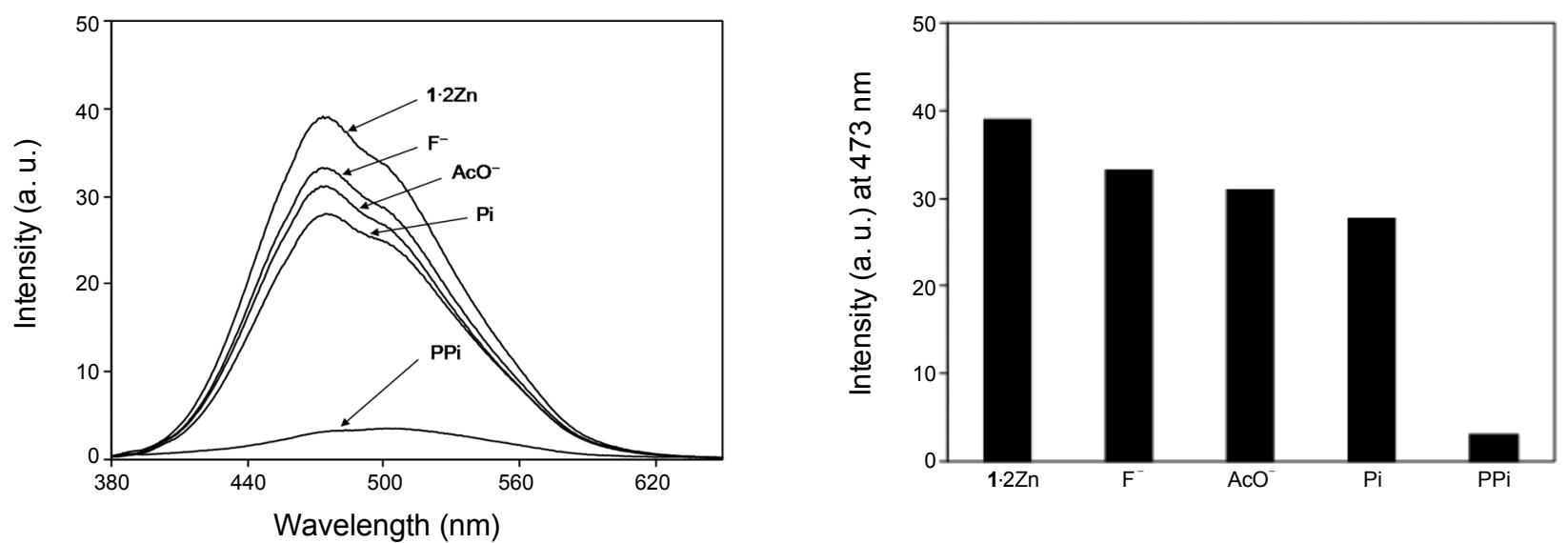

Figure 2. (Left) Fluorescence emission changes $\left(\lambda_{\mathrm{ex}}=355 \mathrm{~nm}\right)$ of $1 \cdot 2 \mathrm{Zn}(5.56 \mu \mathrm{M})$ for various anions such as $\mathrm{F}^{-}, \mathrm{AcO}^{-}, \mathrm{H}_{2} \mathrm{PO}_{4}^{-}$, and $\mathrm{PPi}_{(\mathrm{sodium}}$ salts) in $10 \mathrm{mM}$ HEPES buffer ( $\mathrm{pH} 7.4$ ) at $25^{\circ} \mathrm{C}: \mathrm{F}^{-}=5.43$ equiv (gray line), $\mathrm{AcO}^{-}=5.43$ equiv (orange line), $\mathrm{H}_{2} \mathrm{PO}_{4}^{-}=0.54$ equiv (sky blue line), $\mathrm{PPi}=0.24$ equiv (red line). (Right) Comparison to fluorescence emission intensities $\left(\lambda_{\mathrm{em}}=473 \mathrm{~nm}\right)$ of $1 \cdot 2 \mathrm{Zn}(5.56 \mu \mathrm{M})$ for various anions such as $\mathrm{F}^{-}, \mathrm{AcO}^{-}, \mathrm{H}_{2} \mathrm{PO}_{4}^{-}$, and PPi (sodium salts) in $10 \mathrm{mM}$ HEPES buffer (pH 7.4) at $25^{\circ} \mathrm{C}$.
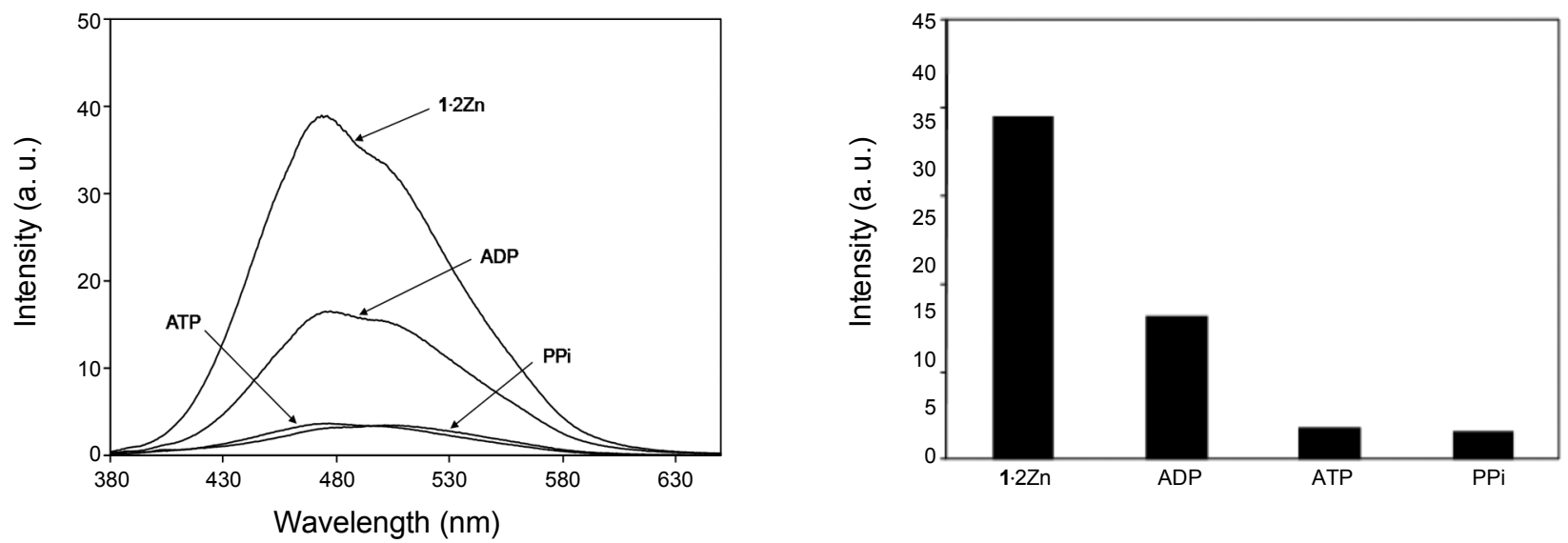

Figure 3. (Left) Fluorescence emission changes $\left(\lambda_{\mathrm{ex}}=355 \mathrm{~nm}\right)$ of $1.2 \mathrm{Zn}(5.56 \mu \mathrm{M})$ in the presence of ADP $(0.54$ equiv), ATP $(0.24$ equiv), and PPi (0.24 equiv) (sodium salts) in $10 \mathrm{mM} \mathrm{HEPES} \mathrm{buffer} \mathrm{(} \mathrm{pH} 7.4)$ at $25^{\circ} \mathrm{C}$. (Right) Relative fluorescence intensities at $476 \mathrm{~nm}$ of $1 \cdot 2 \mathrm{Zn}(5.56$ $\mu \mathrm{M}$ ) and its complexes with ADP, ATP, and PPi (sodium salts) in $10 \mathrm{mM}$ HEPES buffer (pH 7.4) at $25^{\circ} \mathrm{C}$.

Table 1. Fluorescence intensities, quenching ratios, and quenching efficiencies of each anion at $\lambda_{\max }=473 \mathrm{~nm}$ upon the addition of anions (sodium salts) in $10 \mathrm{mM}$ HEPES buffer (pH 7.4) at $25^{\circ} \mathrm{C}$

\begin{tabular}{lccc}
\hline$\lambda_{\max }(473 \mathrm{~nm})$ & F.I. (a.u.) & Q.R. (fold) $^{b}$ & ${\text { Q.E. }(\%)^{c}}^{c}$ \\
\hline Host & 39.08 & & \\
$\mathrm{~F}^{-}$ & 33.20 & 1.1 & 15.1 \\
$\mathrm{AcO}^{-}$ & 30.98 & 1.2 & 20.7 \\
$\mathrm{H}_{2} \mathrm{PO}_{4}^{-}$ & 27.81 & 1.4 & 28.8 \\
$\mathrm{PPi}$ & 3.15 & 12.4 & 92.0
\end{tabular}

${ }^{a}$ F.I. (a.u.): Fluorescence Intensity, ${ }^{b}$ Q.R. (fold): Quenching Ratio, ${ }^{c}$ Q.E. (\%): Quenching Efficiency.

$\mathrm{AcO}^{-}$, and $\mathrm{H}_{2} \mathrm{PO}_{4}^{-}$(sodium salts) in $10 \mathrm{mM}$ HEPES buffer (pH 7.4) at $25^{\circ} \mathrm{C}$ (Fig. 2). While the addition of 0.24 equiv PPi resulted in a 12 -fold decrease in the emission intensity of $\mathbf{1} \cdot 2 \mathrm{Zn}$, however, the addition of 5.4 equiv of $\mathrm{F}^{-}$and $\mathrm{AcO}^{-}$resulted in 1.1-, and 1.2-fold decreases, respectively, in the emission inten- sity at $473 \mathrm{~nm}$, and the addition of 0.54 equiv $\mathrm{H}_{2} \mathrm{PO}_{4}{ }_{4}^{-}$resulted in a 1.4-fold decrease in the emission intensity. Based on the above data, Table 1 shows the values of fluorescence intensity (F.I.), quenching ratio (Q.R.), and quenching efficiency (Q.E.) for each anion at $\lambda_{\max }=473 \mathrm{~nm}$. Therefore, sensor $1 \cdot 2 \mathrm{Zn}$ can sense selectively $\mathrm{PPi}$ relative to other anions such as $\mathrm{F}^{-}, \mathrm{AcO}^{-}$, and $\mathrm{H}_{2} \mathrm{PO}_{4}{ }^{-}$in $10 \mathrm{mM}$ HEPES buffer (pH 7.4) at $25^{\circ} \mathrm{C}$.

We also investigated emission changes of $1.2 \mathrm{Zn}(5.56 \mu \mathrm{M})$ in the presence of ADP and ATP (sodium salts) in $10 \mathrm{mM}$ HEPES buffer (pH 7.4) at $25{ }^{\circ} \mathrm{C}$ (Fig. 3). Addition of 0.54 equiv ADP to $1.2 \mathrm{Zn}$ resulted in approximately 2 -fold decrease in the emission intensity at $476 \mathrm{~nm}$. The fluorescence intensity at $476 \mathrm{~nm}$ of $1.2 \mathrm{Zn}$ after the addition of 0.24 equiv ATP was similar to that of the complex between $1 \cdot 2 \mathrm{Zn}$ and PPi. However, the fluorescence intensity at $505 \mathrm{~nm}$ of the $1: 1$ mixture of $1 \cdot 2 \mathrm{Zn}$ and PPi turned out to be 2.2-fold larger than that of 1.2Zn and ATP. Interestingly, the fluorescence titration curves for ATP $(0 \sim 3.2$ equiv) revealed that the emission intensity continuously decreased at $476 \mathrm{~nm}$ and was almost saturated at 3.2 equiv while those 
for PPi $(0 \sim 3.2$ equiv) displayed ratiometric behavior as shown in Fig. 1.

As expected, a Job's plot for binding between 1.2Zn and PPi showed a 1:1 binding stoichiometry. The binding mode for PPi-1.2Zn was presented in a previous paper from our team involving a similar sensor molecule and its X-ray crystal structure. ${ }^{5}$ When PPi is coordinated to $1 \cdot 2 \mathrm{Zn}$, the negative charge density of the phenolate oxygen atom in $1.2 \mathrm{Zn}$ increases to more than that before binding to PPi. In the previous naphthyl$\mathrm{Zn}$ (II) DPA system, an increased charge characteristic on the phenolate oxygen atom induced a fluorescence enhancement through induced charge transfer. ${ }^{3 \mathrm{c}}$ However, in the case of pyrenyl-Zn(II)·DPA system $(\mathbf{1} \cdot 2 \mathrm{Zn})$, the PET process is expected to take place from the nitrogen atoms of the DPA moiety to pyrene because of the orthogonal conformation (dihedral angle $=$ $-83.60^{\circ}$, Spartan '08 program) between the phenolate and pyrene (Fig. 4) which prohibits extended $\pi$-conjugation through the $\pi$ system involving phenyl and pyrenyl groups. Calculation (Spartan '08 program) shows that excimer formation is possible in $1 \cdot 2 \mathrm{Zn}$ (Fig. 5). Therefore, the PET process induces quenching in the excimer emission of $1 \cdot 2 \mathrm{Zn}$.

In conclusion, we have developed a new fluorescent chemosensor based on the pyrenyl-DPA system which shows the selective quenching effect of excimer emission for PPi relative to other anions through the PET process in water. The quenching effect of the pyrene excimer emission is expected to take place

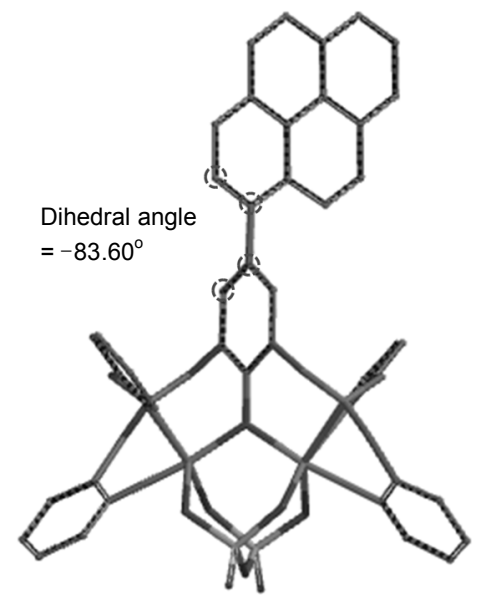

Figure 4. Energy-minimized structure of the complex between $1 \cdot 2 \mathrm{Zn}$ and PPi (Spartan '08 program).

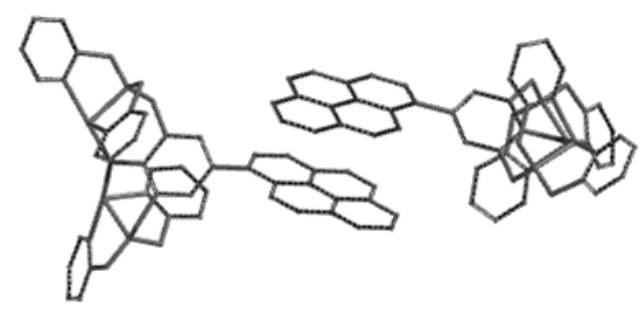

Figure 5. Energy-minimized structure of the excimer formed by two $1 \cdot 2 \mathrm{Zn}$ complexes (Spartan '08 program). through the PET process from the nitrogen lone pair electrons of the DPA moiety to pyrene.

\section{Synthesis and Characterization}

Compound 3. To a solution of compound 2 ( $220 \mathrm{mg}, 1$ equiv), pyrene-1-boronic acid ( $239 \mathrm{mg}, 1.2$ equiv), and $10 \mathrm{~mL}$ of $2 \mathrm{~N}$ aq. $\mathrm{K}_{2} \mathrm{CO}_{3}$ in $5 \mathrm{~mL}$ of distilled THF under $\mathrm{N}_{2}$ gas was added slowly tetrakis(triphenylphosphine)palladium(0) (101 mg, 0.1 equiv). The mixture was heated at reflux temperature for $12 \mathrm{~h}$, which was then filtrated by Celite 545 (washed with THF). The combined organic extracts were evaporated. The residue was chromatographed on silica gel using hexane:EtOAc $=100: 1$ 5:1 to afford compound 4 (120 mg, 38\% yield). ${ }^{1} \mathrm{H}$ NMR (300 $\mathrm{MHz}$, acetone- $\left.d_{6}\right) \delta 1.63(\mathrm{~s}, 6 \mathrm{H}), 4.77(\mathrm{~s}, 2 \mathrm{H}), 5.04(\mathrm{~s}, 2 \mathrm{H})$, $7.27(\mathrm{~s}, 1 \mathrm{H}), 7.65(\mathrm{~s}, 1 \mathrm{H}), 8.01-8.35(\mathrm{~m}, 9 \mathrm{H}) .{ }^{13} \mathrm{CNMR}(75 \mathrm{MHz}$, acetone- $\left.d_{6}\right) \delta 24.30,58.48,60.57,99.77,119.23,124.79,125.13$, 125.27, 126.18, 127.21, 127.33, 127.45, 127.76, 127.96, 130.17, 131.06, 131.59, 132.44. HRMS (FAB): $m / z$ calcd. for $\mathrm{C}_{27} \mathrm{H}_{22} \mathrm{O}_{3}$ $[\mathrm{M}+\mathrm{H}]^{+} 394.1569$, found 394.1572 .

Compound 4. To a stirred solution of compound $3(120 \mathrm{mg}$, 1 equiv) in $4 \mathrm{~mL}$ THF was added $4 \mathrm{~mL}$ of $1 \mathrm{~N} \mathrm{HCl}$. The reaction mixture was stirred at room temperature for 2 days, and then all the volatile components were evaporated and the residue was neutralized with aq. $\mathrm{NaHCO}_{3}$, then partitioned between ethyl acetate and brine. The organic phase was washed with water $(\times 3)$, and then dried in anhydrous $\mathrm{Na}_{2} \mathrm{SO}_{4}$. This solution was evaporated. Flash chromatographic purification (Hexane: EtOAc $=50: 1, \mathrm{v} / \mathrm{v})$ afforded $4(50 \mathrm{mg}, 46 \%$ yield $) .{ }^{1} \mathrm{H} \mathrm{NMR}$ $\left(300 \mathrm{MHz}, \mathrm{CDCl}_{3}\right) \delta 4.99(\mathrm{~s}, 4 \mathrm{H}), 7.38(\mathrm{~s}, 2 \mathrm{H}), 7.93-8.23(\mathrm{~m}$, $9 \mathrm{H}) .{ }^{13} \mathrm{C}$ NMR $\left(75 \mathrm{MHz}\right.$, acetone- $\left.d_{6}\right) \delta 61.33,124.76,124.80$, $125.07,125.33$, 126.18, 127.14, 127.26, 127.47, 127.78, 128.19, 128.36, 130.27, 131.06, 131.59, 131.70, 138.14, 153.30. HRMS (FAB): $m / z$ calcd. for $\mathrm{C}_{24} \mathrm{H}_{18} \mathrm{O}_{3}[\mathrm{M}+\mathrm{H}]^{+} 354.1256$, found 354.1257 .

Compound 5. To a stirred solution of compound 4 (50 mg, 1 equiv) in $10 \mathrm{~mL}$ of THF was added aq. $\mathrm{NaOH}$ ( $45 \mathrm{mg}, 8$ equiv) at $0{ }^{\circ} \mathrm{C}$. To this solution was added $p$-toluenesulfonyl chloride ( $214 \mathrm{mg}, 8$ equiv) dissolved in $10 \mathrm{~mL}$ of THF. The reaction mixture was stirred at $0{ }^{\circ} \mathrm{C}$ for $4 \mathrm{~h}$, and then all the volatile components were evaporated and the residue was neutralized with $1 \mathrm{~N} \mathrm{HCl}$ and was partitioned between ethyl acetate and brine. The organic phase was washed with water $(\times 3)$, and then dried in anhydrous $\mathrm{Na}_{2} \mathrm{SO}_{4}$. Flash chromatographic purification (Hexane:EtOAc = 10:1 - 3:1, v/v) afforded $5(12 \mathrm{mg}, 10 \%$ yield). ${ }^{1} \mathrm{H}$ NMR (300 MHz, acetone- $\left.d_{6}\right) \delta 2.36(\mathrm{~s}, 6 \mathrm{H}), 2.57(\mathrm{~s}, 3 \mathrm{H})$, $5.20(\mathrm{~s}, 4 \mathrm{H}), 7.40(\mathrm{~d}, J=8.2 \mathrm{~Hz}, 4 \mathrm{H}), 7.62-7.65(\mathrm{~m}, 4 \mathrm{H}), 7.90$ $(\mathrm{d}, J=8.3 \mathrm{~Hz}, 4 \mathrm{H}), 8.00(\mathrm{~d}, J=8.2 \mathrm{~Hz}, 2 \mathrm{H}), 8.13-8.39$ (m, 9H). ${ }^{13} \mathrm{C} \mathrm{NMR}\left(75 \mathrm{MHz}, \mathrm{CDCl}_{3}\right) \delta 21.57,21.91,66.41,124.35$, $124.63,125.21,125.55,126.27,127.32,127.90,128.16,128.26$, $128.42,129.18,129.86,130.38,131.43,132.77,132.96,140.90$, 142.91, 145.02. HRMS (FAB): $m / z$ calcd. for $\mathrm{C}_{45} \mathrm{H}_{36} \mathrm{O}_{9} \mathrm{~S}_{3}[\mathrm{M}+\mathrm{H}]^{+}$ 816.1521 , found 816.1517 .

Compound 1. To a solution of 5 (12 mg, 1 equiv) in acetonitrile were added 3 equiv of $\mathrm{KI}(7.5 \mathrm{mg}), 3$ equiv of $\mathrm{Cs}_{2} \mathrm{CO}_{3}$ $(15 \mathrm{mg})$ and 2.1 equiv of dipicolylamine $(6.3 \mathrm{mg})$. The reaction mixture was stirred at $40{ }^{\circ} \mathrm{C}$ overnight, and then all the volatile components were evaporated. The resulting residue was extracted with ethylacetate/brine. The organic phase was washed with 
water $(\times 3)$, then dried in anhydrous $\mathrm{Na}_{2} \mathrm{SO}_{4}$, and evaporated. To the resulting solution was added aq. $\mathrm{KOH}$ (20 equiv) for hydrolysis. The reaction mixture was stirred at room temperature for $24 \mathrm{~h}$. The mixture was then neutralized with $1 \mathrm{~N} \mathrm{HCl}$, and partitioned between ethyl acetate and water. The organic phase was washed with water $(\times 3)$, and then dried in anhydrous $\mathrm{Na}_{2} \mathrm{SO}_{4}$. Flash chromatographic purification $\left(\mathrm{CH}_{2} \mathrm{Cl}_{2}: \mathrm{MeOH}=\right.$ 100:1 - 20:1) afforded 1 (5 mg, 47\% yield). ${ }^{1} \mathrm{H} \mathrm{NMR} \mathrm{(300} \mathrm{MHz,}$ acetone- $\left.d_{6}\right) \delta 3.96(\mathrm{~s}, 4 \mathrm{H}), 3.98(\mathrm{~s}, 8 \mathrm{H}), 7.22(\mathrm{t}, 4 \mathrm{H}, J=11.5$ $\mathrm{Hz}), 7.58-7.59(\mathrm{~m}, 6 \mathrm{H}), 7.68(\mathrm{t}, 4 \mathrm{H}, J=9.1 \mathrm{~Hz}), 7.99-8.28(\mathrm{~m}$, $9 \mathrm{H}), 8.54(\mathrm{~d}, 4 \mathrm{H}, J=4.2 \mathrm{~Hz}$ ). HRMS (FAB): $\mathrm{m} / \mathrm{z}$ calcd. for $\mathrm{C}_{48} \mathrm{H}_{40} \mathrm{~N}_{6} \mathrm{O}[\mathrm{M}+\mathrm{H}]^{+}$717.3342, found 717.3355.

Sensor 1.2Zn. To a solution of $1(1.1 \mathrm{mg})$ in $1 \mathrm{~mL}$ of $\mathrm{MeOH}$, was added an aqueous solution of $\mathrm{Zn}\left(\mathrm{NO}_{3}\right)_{2} \cdot 6 \mathrm{H}_{2} \mathrm{O}$ (2.1 equiv), and the mixture was stirred for $30 \mathrm{~min}$ at room temperature. $1 \cdot 2 \mathrm{Zn}$ was then dissolved in $10 \mathrm{mM}$ HEPES buffer ( $\mathrm{pH} 7.4$ ) and used as a stock solution for complexation studies. HRMS (FAB): $m / z$ calcd. for $\mathrm{C}_{48} \mathrm{H}_{40} \mathrm{~N}_{6} \mathrm{O} \cdot 2 \mathrm{Zn} \cdot 2 \mathrm{NO}_{3}[\mathrm{M}]^{+} 967.1525$, found 967.1524 .

Acknowledgments. This study was supported by the NRF grant funded by the MEST (Grant No. 2009-0080734).

\section{References}

1. (a) Limpcombe, W. N.; Sträter, N. Chem. Rev. 1996, 96, 2375. (b) Nyrén, P. Anal. Biochem. 1987, 167, 235. (c) Tabary, T.; Ju, L. J. Immunol. Methods 1992, 156, 55.

2. (a) Ronaghi, M.; Karamohamed, S.; Pettersson, B.; Uhlen, M.; Nyren, P. Anal. Biochem. 1996, 242, 84. (b) Ronaghi, M. Genome Res. 2001, 11, 3. (c) Lee, D. H.; Hong, J.-I. Bull. Kor. Chem. Soc. 2008, 29, 497.

3. (a) Vance, D. H.; Czarnik, A. W. J. Am. Chem. Soc. 1994, 116, 9397. (b) Fabbrizzi, L.; Marcotte, N.; Stomeo, F.; Tagletti, A. Angew. Chem., Int. Ed. 2002, 41, 3811. (c) Lee, D. H.; Kim, S. Y.; Hong, J.-I. Angew. Chem., Int. Ed. 2004, 43, 4777. (d) Lee, H. N.; Xu, Z.; Kim, S. K.; Swamy, K. M. K.; Kim, Y.; Kim, S.-J.; Yoon, J. J. Am. Chem. Soc. 2007, 129, 3828. (e) McDonough, M. J.; Reynolds, A. J.; Lee, W. Y. G.; Jolliffe, K. A. Chem. Commun. 2006, 2971. (f) Kim, S. K.; Lee, D. H.; Hong, J.-I.; Yoon, J. Acc. Chem. Res. 2009, 42, 23.

4. Cho, H. K.; Lee, D. H.; Hong, J.-I. Chem. Commun. 2005, 1690.

5. Lee, D. H.; Im, J. H.; Son, S. U.; Chung, Y. K.; Hong, J.-I. J. Am. Chem. Soc. 2003, 125, 7752.

6. Kim, H. J.; Kim, S. K.; Lee, J. Y.; Kim, J. S. J. Org. Chem. 2006, 71,6611 .

7. Wu, F.-Y.; Bae, S. W.; Hong, J.-I. Tet. Lett. 2006, 47, 8851. 